\title{
Adoption of Information Technology in U.S. Hotels: Strategically Driven Objectives
}

\author{
Judy A. Siguaw \\ Cornell University \\ Cathy A. Enz \\ Cornell University \\ Karthik Namasivayam \\ Cornell University
}

Using two unique, independent samples of U.S. hotels, this study examines the utilization of information technology (IT) in all hotel sectors, from deluxe to budget, to reveal strategic differences and similarities. Overall, the findings suggest that the U.S. lodging industry has focused on employing technologies that improve employee productivity and enhance revenue but has not given strategic priority to technologies designed to improve guest services. The hotel sector, lodging type, size/complexity of the property, and independent versus chain affiliation influenced the number and type of technologies adopted. Luxury and upscale hotels adopted more IT than economy and budget hotels. Similarly, IT development was greatest for certain lodging types such as convention hotels, conference centers, and casinos, and lowest for other types, such as motels and bed-and-breakfasts. Chain-affiliated properties typically adopted more technologies than independent hotels.

The use of information technology (IT) within the hospitality industry is driven by the desire to refine customer service (Sweat and Hibbard 1999), improve operations (Bachel- dor 1999), increase revenues, and minimize costs (Huo 1998). Furthermore, several studies have identified a positive and significant relationship between the use of IT and the development of a competitive advantage (e.g., Cho and Olsen 1998; Clemons 1986; McFarlan 1984; Porter 1985). Given the benefits of IT touted in the literature, the extensive use of technology within the lodging industry would appear to be a foregone conclusion.

Yet, the degree to which the hospitality industry has embraced technological innovations appears equivocal. Some researchers maintain that the adoption of technology within the hospitality industry is extensive. For example, Cho and Olsen (1998) state, "Evidence of the acceptability and widespread use of IT is visible in many aspects of the service industry in 
general and in the lodging industry in particular" (p. 376). On the other hand, several industry experts suggest that the lodging industry lags behind other industries in the implementation of new IT (Meyers 1999; Whitford 1999; Woodyard 1999). Specifically, a study by Arthur Andersen (1999) finds that fewer than half of the hotels in the United States have widely integrated IT systems in place. Perhaps the (un)willingness of the various segments of the hospitality industry to openly embrace technology may be explained by strategic choices (c.f. Keltner et al. 1999), yet research on technological adoption within this context has been almost nonexistent. Given the sweeping effects IT signifies for the hospitality industry and the absence of research, a comprehensive study examining the extensiveness of and strategic priorities that form technology in the lodging industry appears highly warranted.

In response to this need, herein are presented the results of an investigation of IT adoption and innovation drawn from a survey of current technology utilization in more than 4,000 U.S. hotels, and case studies from an expansive, complex study of best practices in IT spanning all sectors of the U.S. lodging industry. These two databases are used to explore how three key strategic areas-improved guest services, increased employee productivity, and enhanced revenue generation - are prioritized when developing and choosing a broad range of information technologies. Do some strategic concerns have precedence when selecting IT? Does the IT deployed follow an industry-wide pattern, or does it vary by the chosen lodging segment, brand affiliation status, administrative complexity, or lodging type? It is hoped that by examining the preference given the three strategic areas noted, a greater understanding of current patterns of IT adoption within the U.S. lodging industry will be gained. Furthermore, it is reasoned that the strategic priorities that guide IT adoption will differ depending on the customer segment served by the chosen lodging segment (e.g., budget, economy, midprice, upscale, and luxury), complexity of the hotel operation (i.e., number of rooms), the hotel brand affiliation (chain or independent), and the lodging type (i.e., all suite, extended stay, convention hotel, casino hotel, standard hotel, motel, or bed-and-breakfast). Finally, this study will highlight the practices of 11 industry innovators to provide insights from current managers on their experiences in the adoption of new IT practices.

This study, based on two unique independent samples of U.S. hotels, incorporates a thorough examination of IT utilization in deluxe to budget hotel companies in an effort to reveal strategic differences and similarities within the U.S. lodging industry. As such, this work provides insight on the various priorities that guide the use of IT and how technological innovations can range from the simple to the elaborate. Execution issues and suggestions for the effective introduction of technology are surfaced from the best practice champions identified as exemplary for their IT innovations. The article concludes with a discussion of the significance of the findings as they pertain to managers seeking to incorporate IT innovations as a means of attaining competitive advantage, specifically through improved guest service, increased employee productivity, and enhanced revenue generation. An effort to understand the alignment of IT to strategic intention in various U.S. lodging segments is the unique contribution of this study. 


\section{Justification and Research Questions}

Authors of best-selling works strongly advocate the reorganization of work processes as a means of improving performance (Champy 1996; Hammer 1996; Senge 1994; Senge et al. 1999). To accomplish this restructuring, Baker (1999) notes that IT, including e-commerce, will play a critical role because it allows for altering "relationships and the flow of information so that the right parties can obtain it at the right time" (p. 32). Hence, IT initiatives are expected to restructure organizational processes and corporate culture and, in turn, develop "entirely new business capacities" (p. 32). Yet, the degree to which service industries are embracing IT as a means of restructuring organizational processes varies widely.

To grasp why this wide variation in the adoption of technology exists, some understanding of the process by which the implementation of IT occurs is helpful. King et al. (1994) noted that six organizational actions stimulate the adoption of IT: knowledge building, knowledge deployment, subsidies, mobilization, standard setting, and innovation directives. Knowledge building is composed of activities designed to provide the technical knowledge needed to use technological innovations. Knowledge deployment consists of activities that disseminate the technical knowledge to potential users of the innovations. Subsidies are the supporting funds provided to purchase or develop the innovations. Mobilization is composed of the communication activities designed to gain acceptance of the innovation from all affected parties. Standards setting are those actions that guarantee uniformity within the technology so that it can be used within and across a variety of organizations. Innovation directives are those commands that require that the technological innovations be used.

McKenney (1994) identified five stages through which firms progress as IT is adopted. First, IT is embraced for the purpose of finding a solution to a problem. Second, IT is used to build competence and, third, to expand the solution. Fourth, IT is implemented to enable change (increase productivity through improved services and lower costs) and, fifth, to evolve strategy that will create a competitive advantage. In conjunction with McKenney's work, Montealegre (1999) noted that in the first phase of the process - finding a solution to a problem-organizations "settled for rudimentary connection that fit their resources, skills, and existing technology" (p. 224). Consistent with King et al. (1994), Montealegre (1999) also found, "The adoption of state-of-the-art technologies ... requires different managerial, technical, and financial resources than those needed to adopt mature technologies offered and supported by an experienced vendor base" (p. 225).

Closely related to McKenney's (1994) fifth phase of using technology to create a strategic competitive advantage, Keltner et al. (1999) has sought to explain the adoption of technology as a function of strategic choice. Indeed, Keltner et al.'s research indicates that service companies' wide variation in the use of technology to improve efficiency may be intentional. That is, "many U.S. service companies may effectively be achieving lower productivity by design" to achieve "a strategic alignment between customer segmentation strategies and organizational capability development" (p. 85). A hotel's preference for a 
particular strategy or set of strategies also likely depends on the relative cost of achieving the strategy, the customer's response to the strategy, and the hotel's capabilities and motivations (c.f., Glazer 1999). Consequently, hotels would be expected to focus on a select set of technology initiatives that are tied to a specific strategy. Following this line of reasoning, as well as Keltner et al.'s (1999), within low value-added lodging segments (budget, economy, and midscale), hotels are likely to pursue information technologies that increase operating efficiency; whereas within high value-added lodging sectors (upscale and luxury), hotels are likely to initiate technological improvements that increase the quality of service delivery to the guest.

As a result of the previous studies, the following research questions are investigated: First, per McKenney (1994), What strategic priorities (customer service, revenue enhancement, or employee productivity) are most critical in the selection of information technologies? Second, in accordance with Keltner et al. (1999), Do information technologies vary within the lodging industry depending on the lodging segment, the organization's administrative complexity, its brand affiliation, and its lodging type? Is the adoption of technologies clustered to accomplish specific organizational strategies? Are the technological initiatives of lowcustomer-service hotel sectors focusing on employee productivity as a means to achieve operational efficiencies, while the technologies of high-customer-service hotel sectors focus on guest-pleasing and service delivery strategies, as Keltner et al. suggest? Finally, per King et al. (1994), Are there specific lessons to be learned when introducing IT that enhances its likelihood of successful implementation?

\section{Methodology}

\section{Data Collection}

The data for this study were obtained from two sources. First, data on hotel properties were culled from the American Hotel and Motel Association's 1998 Lodging Survey conducted by RealTime Hotel Reports Inc. (RTHR). rThR's database covers $98 \%$ of all properties in the United States. As part of their original survey, RTHR faxed or mailed surveys to 32,934 hotels. Following the original survey, two more attempts via fax or mail were made to reach nonrespondents. All questions on the survey could be answered with a "yes"/ "no" response. More than 9,370 hotels responded; however, this data set was further reduced to 5,287 properties by selecting out hotels that did not respond to any of the questions on technology adoption. This subset of 5,287 properties was used in the data analysis for this study.

In addition, best practice cases were drawn from a study conducted of best practices in the U.S. lodging industry (Dube et al. 1999; Siguaw and Enz 1999). This second data set incorporates the findings from 11 case studies of IT best practice champions selected from a comprehensive survey of 13,459 managers, which yielded 3,528 industry nominations. Through a process of filtering, a final list of 140 best practice champions in all areas of management were interviewed. The case examples included here were drawn from interviews with the 11 IT 
champions. The results of these interviews illustrate the role IT plays and offer insights on how to implement IT. The cases from IT best practice champions provide a rich source of personal insights from adopters of new IT who are regarded as the best of the best by their peers in our comprehensive survey of both corporate and property level managers.

\section{Measures}

Strategic priorities. Ten information technologies were selected from the 1998 Lodging Survey, representing each of the three primary strategic priorities: improved guest services, increased employee productivity, and enhanced revenue. Technologies subsumed under efforts to improve guest services included in-room modem, in-room Internet access, and in-room fax machine. These technologies are grouped together because all guests are recipients of the benefits these amenities offer, if the guests so choose to use them. No separate purchase decision is required for the use of these in-room technologies.

Technological innovations designed to improve employee productivity included voicemail, interactive guide, and management e-mail. Voice-mail and interactive guides allow automation of the service delivery system, thus reducing the guest-communications workload of the front office and concierge staff and allowing time for a greater focus on other guest services. Management e-mail allows for greater crossdepartment and cross-hotel communications and greater connectivity with corporate headquarters. E-mail ensures the rapid dissemination of knowledge and allows for an immediate response. Furthermore, administrative staff do not have to serve as an intermediary for these communications, as they might for incoming telephone calls or mail, therefore allowing them to focus their efforts elsewhere. These services also improve the overall property productivity by improving staffing ratios.

Finally, the revenue-enhancing strategic category included Internet bookings, teleconferencing, cell phone rentals, and automatic teller machines (ATMs). The Internet reservation option serves as an additional channel of distribution meant to capture incremental bookings. Furthermore, the Internet reduces the need for middlemen, thereby reducing the associated costs of commissions. Cell phone rentals are an added-value option that provides a direct revenue stream. ATMs also serve as a direct source of revenue; Marshall (1999) reports that some resorts receive "a healthy share of the ATM transaction fee revenues" (p. 63). Finally, teleconferencing equipment and applications provide a strong profit margin.

Hotel variables. Administrative complexity was measured by counting the number of rooms in each of the responding hotels. The larger the number of hotel rooms, the more complex the operation. This conceptualization of administrative complexity has a rich historical precedence in the organizational theory literature (Dewar and Hage 1978). Lodging segment was determined using a self-report question in which the respondents self-identified their value-added hotel sector (budget, economy, midprice, upscale, luxury). Finally, brand affiliation status was based on a distinction between those hotels with chain affiliations and those that 
maintain independent status. Lodging type was self-reported by the respondents; each hotel was identified as an all-suite, extended stay, convention hotel, casino, conference center, condominiums, standard, motel, or bed-and-breakfast.

\section{Analysis}

After the technologies were categorized by their fit with each of the three strategic priorities, simple frequencies were run on the database of 5,287 properties to determine to what extent the U.S. lodging industry overall appears to be adopting recent technological innovations. Then, the data were grouped so technology adoption could be examined by lodging segment (budget, economy, midscale, upscale, and luxury), lodging type (all-suite, extended stay, convention hotel, casino, standard hotel, motel, and bed-and-breakfast), and hotel size (number of rooms: < 20, 21-30, 31-60, 61-100, 101-150, 151-200, 201-250, 251-500, $501-1,000,>1,000)$. The ability to analyze the data by hotel sector is important since Keltner et al. (1999) has noted, "Industries may not be the most appropriate level of analysis for the study of service sector productivity" (p. 99). Instead, the analysis at hand is most appropriately conducted by examining the variation across the sectors of the lodging industry; therefore, oneway ANOVA and post hoc comparison tests utilizing Scheffe's method were used to evaluate differences across groups.

\section{Results and Discussion}

\section{Overall Industry Findings}

Of the 9,351 hotel properties included in this study, 4,064 (43.5\%) did not respond to questions regarding the adoption of technology; consequently, this group was dropped from the analysis for the research at hand. Of the 5,287 properties included in this study, 608 (11.5\%) indicated they have adopted no technologies; whereas, the remainder of 4,679 (88.5\%) properties noted they have embraced technological innovations to at least some degree.

Table 1 shows the extent to which hotels have adopted technological innovations. Of those hotels indicating they had implemented technological innovations, 742 (15.9\%) had adopted only 1 technology, 1,183 (25.3\%) had adopted 2, and 1,056 (22.6\%) had adopted 3. Some properties were medium users of technology; that is, 802 (17.1\%) had adopted 4, 478 $(10.2 \%)$ had adopted 5 , and $216(4.6 \%)$ had adopted 6 . Finally, some properties were heavy users of technology; for example, 116 (2.2\%) had adopted 7 different technologies, 60 (1.3\%) had adopted 8 , and $26(0.6 \%)$ had adopted 9 or 10.

The single most frequently used innovation by the 4,679 properties that had adopted at least 1 technology was participation in an interactive Web site that allowed reservations to be made via the Internet. A total of 3,480 (74.3\% of the technology properties) chose to embrace this technology. Closely tied for first choice in innovations were e-mail systems for property managers $(3,250$ or $69.5 \%)$, somewhat distantly followed by in-room modems $(2,626$ or $56.1 \%)$ and voice mail (2,141 or $45.8 \%)$. Other technologies adopted included, in descending order, 
interactive television guide (942 or $20.1 \%$ ), teleconferencing ( 723 or $15.5 \%$ ), ATM (676 or $14.4 \%)$, Internet access for guests (363 or $7.8 \%$ ), cell phone rentals (308 or $6.6 \%$ ), and an inroom fax machine (191 or 4.1\%). Table 2 provides the distribution of hotels using each of the 10 technologies discussed above.

\begin{tabular}{lcc}
\hline \hline $\begin{array}{l}\text { Number of } \\
\text { Technologies Adopted }\end{array}$ & Frequency & $\begin{array}{c}\text { Percentage } \\
\text { of Total }\end{array}$ \\
\hline 1 & 742 & 15.9 \\
2 & 1,183 & 25.3 \\
3 & 1,056 & 22.6 \\
4 & 802 & 17.1 \\
5 & 478 & 10.2 \\
6 & 216 & 4.6 \\
7 & 116 & 2.5 \\
8 & 60 & 1.3 \\
$9 / 10$ & 26 & 0.6 \\
Total number of properties & 4,679 & 100.0 \\
\hline
\end{tabular}

Note: A total of 608 hotels report the use of no technologies.

Table 1 Frequency distribution of technology adoptions

Regarding implementation of technological innovations to assist in achieving organizational strategies, hotels focused on improving employee efficiency and increasing revenue, as shown in Table 3. In total, 3,930 (83.9\%) properties adopted voice mail, interactive television guides, and/or management e-mail systems as a means of increasing operational productivity. The next strategic area that the hotels appeared to restructure via technology was revenue extensions. Some 3,759 (80.3\%) properties offered teleconferencing services, cell phone rentals, ATMs, and/or Internet reservations as a means of increasing profitability through extensions to traditional revenue sources. Finally, only 2,814 (60.1\%) hotels used technologies aimed at improving guest services, such as in-room Internet access, in-room fax machines, and in-room modems. The differences in focus on these strategic priorities, as Keltner et al. (1999) suggested, may be determined by factors such as lodging segment, lodging type, brand affiliation status, and administrative complexity. This possibility is examined in the following sections.

\section{Findings by Lodging Segment}

Technology adoption was significantly different across targeted lodging segments as determined by the hotel's value- added sector (i.e., budget, economy, midprice, upscale, luxury; $F=236.79, d f=4, p=.000$ ). Post hoc comparison tests, reported in Table 4, indicated that there were significant differences in means between all five lodging segments; furthermore, the means indicate that as hotels advance along the value-added continuum, they implement a greater number of technologies. 


\begin{tabular}{lcc}
\hline \hline Technology Adopted & Frequency & $\begin{array}{c}\text { Percentage } \\
\text { of Total }\end{array}$ \\
\hline Internet reservations & 3,480 & 74.4 \\
Management e-mail system & 3,250 & 69.5 \\
In-room modems & 2,626 & 56.1 \\
Voice mail & 2,141 & 45.8 \\
Interactive television guide & 942 & 20.1 \\
Teleconferencing & 723 & 15.5 \\
Automatic teller machines & 676 & 14.4 \\
In-room Internet access & 363 & 7.8 \\
Cell phone rentals & 308 & 6.6 \\
In-room fax machine & 191 & 4.1 \\
\hline
\end{tabular}

Note: Numbers do not add up to total number because properties have more than one technology.

Table 2 Frequency distribution of individual technology adoptions $(N=4,679)$

\begin{tabular}{lcc}
\hline \hline $\begin{array}{l}\text { Strategic } \\
\text { Technology Priorities }\end{array}$ & Frequency & $\begin{array}{c}\text { Percentage } \\
\text { of Total }\end{array}$ \\
\hline Guest service & 2,814 & 60.1 \\
Employee productivity & 3,930 & 83.9 \\
Revenue enhancement & 3,759 & 80.3 \\
\hline
\end{tabular}

Table 3 Frequency distribution of strategic technology priorities $(N=4,679)$

Guest service strategic priority. Additional analyses indicate that high value-added hotels do focus on technologies that enhance guest service more so than low value-added hotels ( $F=$ $171.08, d f=4, p=.000)$. In accordance with Keltner et al.'s (1999) views, post hoc comparisons indicate that luxury hotels $(M=5.31)$ offer more technologies to enhance guest services than any other hotel sector $(p=.000)$. Similarly, upscale hotels $(\mathrm{M}=4.66)$ offer more guest service technologies than midscale properties $(p=.000)$, and midscale properties $(M=3.43)$ offer more than economy or budget properties ( $p s=.000$ and .009 , respectively). There was no difference, however, in the technologies offered to enhance guest services in economy and budget hotels $(M s=2.81$ and 2.65 , respectively; $p=.974)$.

These findings are substantiated by our sample of IT case studies. In these case studies, the hotels at which technologies were implemented to improve guest services overwhelmingly fell into the luxury category. For example, The Balsams, a deluxe grand resort, developed a comprehensive, richly detailed guest history system, in which every guest's wish and whim is entered. The Ritz-Carlton Chicago developed a "compcierge" position to assist guests with their computer-related problems, and constantly upgrades hardware and software within its business center. Similarly, the Hotel Nikko Beverly Hills installed a portable (not cellular) telephone system, which allows guests to make and receive telephone calls from a single phone from anywhere in the hotel. 
Employee productivity strategic priority. Our analyses indicated that the value-added hotel sector also influenced the implementation of strategies to improve employee productivity $(F=157.44, d f=4, p=.000)$. Surprisingly, though, the lower value-added hotels were

\begin{tabular}{lcccccc}
\hline \hline & \multicolumn{5}{c}{ Segment } & \\
\cline { 2 - 6 } Strategic Technology Priority & Budget & Economy & Midprice & Upscale & Luxury & $F^{\mathrm{a}}$ \\
\hline Guest service & $2.65_{\mathrm{a}}$ & $2.81_{\mathrm{b}}$ & $3.44_{\mathrm{c}, \mathrm{b}}$ & $4.66_{\mathrm{c}, \mathrm{b}}$ & $5.31_{\mathrm{c}, \mathrm{b}}$ & \multirow{2}{*}{171.1} \\
& $(1.77)$ & $(1.29)$ & $(1.42)$ & $(1.68)$ & $(1.74)$ & \\
Employee productivity & $2.50_{\mathrm{a}}$ & $2.69_{\mathrm{b}}$ & $3.22_{\mathrm{b}}$ & $4.14_{\mathrm{b}}$ & $4.77_{\mathrm{b}}$ & 157.44 \\
& $(1.45)$ & $(1.16)$ & $(1.35)$ & $(1.73)$ & $(1.90)$ & \\
Revenue enhancement & $2.44_{\mathrm{a}}$ & $2.61_{\mathrm{b}}$ & $3.22_{\mathrm{b}}$ & $4.26_{\mathrm{b}}$ & $4.90_{\mathrm{b}}$ & 186.55 \\
& $(1.47)$ & $(1.2)$ & $(1.37)$ & $(1.73)$ & $(1.87)$ & \\
\hline
\end{tabular}

Note: Standard deviations are in parentheses. Means with the same subscript are significantly different at the .05 level. a. Significant at the .001 level.

Table 4 Implementation of technologies by segment (means)

not the leaders in implementing this type of technology; this finding is contrary to results of Keltner et al. (1999). Instead, luxury hotels led in adopting technologies to increase staff efficiency $(M=4.77, p=.000)$. Luxury hotels were followed by upscale hotels $(M=$ $4.14, p=.000)$ in implementing efficiency-creating technologies, then midscale hotels $(M=$ $3.22, p=.000)$. There were no significant differences in the number of technologies to improve productivity adopted by economy and budget hotels ( $M s=2.69$ and 2.50, respectively; $p=.896)$.

On the other hand, our case studies illustrating IT practices to improve employee productivity were heavily weighted with hotels in the midscale sector. This finding is somewhat consistent with Keltner et al. (1999) but counter to our previously discussed finding that indicates luxury hotels implement more technology to improve employee efficiency. For example, in the Candlewood Hotels case study, this midtier, extended-stay hotel company recognized that accounting personnel were spending hours searching through boxes and file cabinets to locate needed documents. As a result, Candle- wood implemented an electronic system that records and images almost $100 \%$ of its accounting and construction records to allow for quick and easy access to documents. Courtyard by Marriott wanted to improve its ability to communicate with, and train and develop managers. Courtyard instituted an intranet information system that provides timely and accurate information to each property and allows electronic technology to replace manuals and other printed information. This system saves employee time and has reduced the need for midlevel supervisors. Likewise, Cendant Corporation integrated all of its economy and midscale properties' MIS functions into one system as a means of improving hotel efficiency. The system integrates central reservations with the property management system, provides enhanced communication between and across all properties and corporate, and improves direct marketing. Finally, Promus Hotel Corporation, whose properties fall into the midscale and upscale categories, developed an online payroll- and benefit accounting system after recognizing that traditional paper forms 
created many errors and required that corporate personnel spend substantial time entering the data into the company system.

Revenue-enhancing strategic priority. Similar results were obtained for the implementation of technologies related to revenue enhancement in that the lodging segment did influence the number of revenue-enhancing technologies adopted $(F=186.55, d f=$ $4, p=.000)$. Luxury hotels again led with the number of technologies implemented to increase revenue $(M=4.90, p=.000)$, followed by upscale properties $(M=4.26, p=$ $.000)$ and midscale hotels $(M=3.22, p=.000)$. No differences in the number of revenueenhancing technologies were found between economy and budget hotels ( $M S=$ 2.61 and 2.44, respectively; $p=.923$ ).

In accordance with these findings, case studies of IT designed to increase profitability were primarily relegated to the upscale hotel sector. Carlson Hospitality Worldwide developed the most productive and cost-effective reservations system in the industry, and through its Radisson division has also instituted a frequent-booker program for travel agents that provides a competitive advantage over other hotel companies. Kimpton Group Hotels and Restaurants and Outrigger Hotels and Resorts, in a joint effort, developed a private-label central reservation system for each hotel chain that allows for a powerful cross-selling capability. The system has substantially improved occupancy rates and ADR. Omni Hotels integrated its company-wide property management system with its reservations systems to yield a reservations system that works in conjunction with the revenue management system. The system has reduced overbookings and increased revenues. Finally, Marriott International has created a revenue management system that uses existing market data to create booking forecasts for each property. This information has enabled Marriott to optimize room revenue by increasing room sales.

\section{Findings by Lodging Type}

Table 5 reports the ANOVA results and post hoc tests for nine different types of lodging product types. Main effects for significant differences in group means were found in technological adoptions across lodging types (e.g., all-suites, extended-stay, casino hotel, etc.; $F=138.23, d f=8, p=.000$ ); however, no differences were found in the implementation of technology between all-suite and casino hotels ( $p=.999)$ and between extended-stay and standard hotels ( $p=.614)$.

Guest services strategic priority. The findings supported our speculation that lodging type serves to influence the adoption of technologies supporting guest services ( $F=$ 88.33, $d f=8, p=.000$ ). Convention and casino hotels implemented the most number of technologies to improve guest services ( $M s=5.52$ and 5.09 , respectively), but the means of these two lodging types were not significantly different $(p=.990)$. In terms of sheer number of adoptions, these two lodging types were followed by all-suite properties $(M=4.25)$, standard hotels $(M=3.96)$, extended stay properties $(M=3.77)$, bed-and-breakfast 


\begin{tabular}{|c|c|c|c|c|c|c|c|c|c|c|}
\hline \multirow[b]{2}{*}{$\begin{array}{l}\text { Strategic } \\
\text { Technology } \\
\text { Priorities }\end{array}$} & \multicolumn{9}{|c|}{ Lodging Type } & \multirow[b]{2}{*}{$F^{\mathrm{a}}$} \\
\hline & $\begin{array}{c}\text { All } \\
\text { Suite }\end{array}$ & $\begin{array}{l}\text { Extended } \\
\text { Stay }\end{array}$ & $\begin{array}{l}\text { Con- } \\
\text { vention } \\
\text { Center }\end{array}$ & Casino & $\begin{array}{l}\text { Con- } \\
\text { ference } \\
\text { Center }\end{array}$ & $\begin{array}{l}\text { Condo } \\
\text { Villa }\end{array}$ & Standard & Motel & $\begin{array}{l}\text { Bed-and- } \\
\text { Breakfast }\end{array}$ & \\
\hline Guest service & $\begin{array}{l}4.25_{a, c} \\
(1.60)\end{array}$ & $\begin{array}{l}3.77_{b, c} \\
(1.25)\end{array}$ & $\begin{array}{l}5.52_{a, b, c} \\
(1.91)\end{array}$ & $\begin{array}{l}5.10_{d} \\
(1.34)\end{array}$ & $\begin{array}{l}4.63_{b, c, e} \\
(1.54)\end{array}$ & $\begin{array}{l}3.97_{\mathrm{c}} \\
(1.35)\end{array}$ & $\begin{array}{l}3.96_{c, e, f} \\
(1.58)\end{array}$ & $\begin{array}{l}2.75_{a, b, c, d, e, f, g} \\
(1.28)\end{array}$ & $\begin{array}{l}3.50_{a, c, d, e, g} \\
(1.27)\end{array}$ & 88.33 \\
\hline $\begin{array}{l}\text { Employee } \\
\text { productivity }\end{array}$ & $\begin{array}{l}4.00_{a} \\
(1.58)\end{array}$ & $\begin{array}{l}3.30_{\mathrm{b}, \mathrm{a}} \\
(1.32)\end{array}$ & $\begin{array}{l}5.12_{\mathrm{a}, \mathrm{c}} \\
(1.96)\end{array}$ & $\begin{array}{l}4.33_{\mathrm{b}, \mathrm{d}} \\
(1.51)\end{array}$ & $\begin{array}{l}4.10_{b, c, e} \\
(1.67)\end{array}$ & $\begin{array}{l}2.77_{\mathrm{a}, \mathrm{c}, \mathrm{d}, \mathrm{e}, \mathrm{f}} \\
(1.21)\end{array}$ & $\begin{array}{l}3.74_{c, f, g} \\
(1.53)\end{array}$ & $\begin{array}{l}2.72_{a, b, c, d, e, g} \\
(1.16)\end{array}$ & $\begin{array}{l}2.81_{a, c, d, e, g} \\
(1.22)\end{array}$ & 98.51 \\
\hline $\begin{array}{l}\text { Revenue } \\
\text { enhancement }\end{array}$ & $\begin{array}{l}4.18_{a} \\
(1.55)\end{array}$ & $\begin{array}{l}3.51_{\mathrm{b}} \\
(1.26)\end{array}$ & $\begin{array}{l}5.29_{a, b, c} \\
(1.86)\end{array}$ & $\begin{array}{l}4.04_{c, d} \\
(1.67)\end{array}$ & $\begin{array}{l}4.22_{b, c, e} \\
(1.63)\end{array}$ & $\begin{array}{l}2.83_{\mathrm{a}, \mathrm{c}, \mathrm{d}, \mathrm{e}, \mathrm{f}} \\
(1.22)\end{array}$ & $\begin{array}{l}3.76_{c, e, t, g} \\
(1.56)\end{array}$ & $\begin{array}{l}2.64_{a, b, c, d, e, g} \\
(1.20)\end{array}$ & $\begin{array}{l}2.84_{a, b, c, d, e, g} \\
(1.23)\end{array}$ & 186.55 \\
\hline
\end{tabular}

Note: Standard deviations are in parentheses. Means with the same subscript are significantly different at the .05 level. a. Significant at the .001 level.

Table 5 Implementation of technology by lodging type (means)

properties $(M=3.5)$, and motels $(M=2.75)$. In post-hoc comparison tests, significant differences in implementation of guest service innovations across lodging types were between all-suite properties and convention, motels, and bed-and-breakfast properties; between extended stay and convention, and motels; between convention hotels and all others, with the exception of casinos; between casinos and motels, and bed-and-breakfast properties; between conference centers and all others except all-suite, casinos, and condos/villas; between condos/villas and convention centers and motels; between standard hotels and motels and conference center properties; and between motels and all other lodging types. All $p$ values for these group comparisons were $<.05$.

Employee productivity strategic priority. Lodging type appears to be a determinant of adoption of technologies to improve employee productivity $(F=98.51, d f=8, p=.000)$. For the most part, convention hotels implemented significantly more innovations to increase staff efficiency than all other lodging types $(M=5.12, p=.000)$ with the exception of casino properties $(p=.238)$. Although the means indicate that convention hotels were followed by casino properties, conference centers, all-suite hotels, and standard hotels ( $M s=$ $4.33,4.09,4.00,3.74$, respectively), the $p$ values indicate no significant differences in the adoption of productivity enhancing technologies for these latter four lodging types $(p=.982$ between casino and all-suites hotels, $p=.998$ for casino and conference centers, $p=0.083$ for conference centers and standard hotels, $p=.379$ for all-suites and standard hotels, and $p=.537$ between casino and standard hotels). Extended-stay hotels, although lower in terms of adopting these types of technologies $(M=3.29)$, were significantly different from all other lodging types except condo/villas $(p=.351)$ and bed-and-breakfasts $(p=.121)$. Motels and bed-and- breakfast properties adopted the fewest productivity-enhancing technologies ( $M s=2.72$ and 2.81, respectively), but the data showed no significant differences between these two lodging types in terms of this type of technology $(p=.998)$.

Revenue-enhancing strategic priority. Further analyses indicated that lodging type had a significant influence on the number of revenue-enhancing technologies adopted $(F=$ $115.14, d f=8, p=.000)$. Convention hotels, of all other lodging types, implemented the 
most technologies to enhance revenue $(M=5.29, p=.000)$. Convention properties were followed by conference centers, all-suite hotels, and casino hotels ( $M s=$ $4.22,4.18$, and 4.04 , respectively), although the number of revenue-enhancing technologies implemented by these three lodging types was not significantly different (all suite and conference center, $p=1.0$; all suite and casino, $p=1.0$ ). Next, extended-stay properties and standard hotels followed ( $M s=3.51$ and 3.76, respectively); again, there was no significant difference in the number of revenue-enhancing technologies adopted by these two lodging types ( $p=.875)$. Motels, condos/villas, and bed-and-breakfast properties had the lowest number of revenue-enhancing technologies ( $M S=2.64,2.83$, and 2.84, respectively), and there was no significant difference between the three lodging types in terms of adopting technologies to increase revenue $(p=.989$ between motels and condos, $p=.807$ between motels and bed-and- breakfasts, and $p=.999$ between bed-and-breakfasts and condos/villas).

\section{Finding by Brand Affiliation Status}

The data analysis, shown in Table 6, also indicated significant differences between chain and independent hotels $(F=111.32, d f=1, p=.000)$. That is, the adoption of technology for chains $(M=3.34)$ was significantly higher than for independents $(M=$ 2.82).

Guest services strategic priority. There was no significant difference between chains and independent properties in terms of adopting technologies to improve guest services $(F=$ $1.23, d f=1, p=.268$ ). Thus, providing a high level of guest services has the same priority level for all hotels regardless of brand affiliation status.

Employee productivity strategic priority. On the other hand, chain-affiliated properties adopted significantly more technologies to improve employee productivity than independent hotels ( $F=176.58, d f=1, p=.000, M s=3.75$ and 3.07, respectively).

Revenue-enhancing strategic priority. In terms of adopting technologies for revenue enhancement, brand affiliation status appeared to be a determinant $(F=91.37, d f=$ $1, p=.000)$, as chain-affiliated properties adopted significantly more technologies to increase revenue than did independent hotels $(M s=3.69$ and 3.17). These latter findings have several possible explanations: (1) increasing revenues and improving productivity may have a greater priority for chain-affiliated properties because of the need to cover costly franchising fees, (2) corporate headquarters may mandate the implementation of certain technologies in all its affiliated properties to ensure that procedures and standards are followed, or (3) due to the greater number of financial and human resources from which they can draw, chains may simply be better at disseminating technological information, training employees, and installing technological equipment. 


\section{Finding by Administrative Complexity}

Main effects were also found for the extent of technological adoption based on differences in administrative complexity, as measured by number of rooms ( $F=$ 213.11.10, $d f=9, p=.000)$. No differences were found in the implementation of technology, however, for relatively small hotels; that is, those hotels falling into the fewer than 20 rooms, 21 to 30 rooms, and 31 to 60 rooms categories were not significantly different ( $M s=2.27,2.07$, and 2.35, respectively; $p>.10$ between all categories). On the other end of the spectrum, no significant differences were found between hotels with 500 to 1,000 rooms and those with more than 1,000 rooms $(M s=6.00$ and 6.13 , respectively; $p=1.000$ ). These results would appear to indicate that up to a certain point (i.e., 60 rooms), hotels can be administratively managed using the same degree of technology; however, beyond that point, as the means confirm, administrative complexity mandates greater implementation of technology. There is a boundary, however, as to how much technology is necessitated by the size of the hotel in that the complexity of managing a hotel of 500 rooms does not appear to require any greater technological implementation than a hotel more than 1,000 rooms. Table 7 summarizes these results.

Guest services strategic priority. The implementation of technologies to increase guest services was significantly and positively influenced by the administrative complexity encountered in managing the hotel $(F=134.86, d f=9, p=.000)$. Post-hoc comparison tests, however, indicate that the main effects of administrative complexity are limited. As might be expected, hotels of fewer than 20 rooms $(M=3.30)$ were significantly different in the adoption of technology to increase guest services from all hotel groups of more than 151 rooms (Ms $=4.11,4.79,5.45,6.52$, and 6.75 for the five size categories comprising hotel groups of more than 151 rooms; $p<.05$ for all comparisons), but were not significantly different from hotels of any smaller size. Hotels of 20 to 30 rooms $(M=2.74)$ were significantly different from all hotels with more than 100 rooms $(p<.05)$ but not from all three smaller size categories $(M s=3.30,2.74$, and 2.82, respectively; $p s=.818,1.000$, and .774, respectively). There were no significant differences in the adoption of guest service innovations in any hotel of 100 rooms or less; however, differences between large hotels ( $>250$ rooms) were significant between hotels with 251 to 500 rooms and hotels with 501 to 1,000 rooms $(p=.000)$. No significant differences were present between hotels that had more than 500 rooms and hotels that had more than 1,000 rooms $(p=1.0)$. The larger hotels accounted for the greatest number of technological adoptions ( $M s=5.45$ for $251-500$ rooms, 6.52 for $501-1,000$ rooms, and 6.75 for $>1,000$ rooms). Themost significant differences for the adoption of guest services technology, in terms of administrative complexity, were found across hotels with 101 to 150 rooms, 151 to 200 rooms, and 201 to 250 rooms ( $M s=3.65$, 4.11, and 4.79; $p<.05$ for all three categories). These findings may indicate that guest services either do not continue to increase in importance as the hotel size grows beyond 501 rooms or that the implementation of additional technologies to increase guest services provides incrementally smaller gains once the administrative complexity extends beyond 501 rooms. That is, there is a 
limit to the number of guest services that can be profitably provided regardless of the hotel size.

\begin{tabular}{lllr}
\hline & \multicolumn{2}{c}{ Brand Affiliation } & \\
\cline { 2 - 3 } Strategic & $\begin{array}{c}\text { Chain } \\
\text { Technology Priorities }\end{array}$ & $\begin{array}{l}\text { Affiliated } \\
\text { Independents }\end{array}$ & $F$ \\
\hline Guest service & 3.77 & 3.71 & \\
& $(1.70)$ & $(1.65)$ & 1.23 \\
Employee productivity & 3.75 & 3.07 & $176.58^{\mathrm{a}}$ \\
& $(1.59)$ & $(1.51)$ & \\
Revenue enhancement & 3.69 & 3.17 & $91.37^{\mathrm{a}}$ \\
& $(1.67)$ & $(1.51)$ & \\
\hline
\end{tabular}

Note: Standard deviations are in parentheses. a. Significant at the .001 level.

Table 6 Implementation of technologies by brand affiliation (means)

Employee productivity strategic priority. Administrative complexity also had a significant influence on the number of technologies adopted to improve employee productivity $(F=$ $173.11, d f=9, p=.000)$; the greater the number of rooms in the hotel, the greater the adoption of technology to increase staff efficiency. In comparison tests, hotels with fewer than 20 rooms, 21 to 30 rooms, or 31 to 60 rooms were not significantly different in the adoption of technological innovations to increase productivity $(M S=2.46,2.35$, and 2.71 , respectively; $p>.10$ for all categories). Likewise, once hotels reached a high level of administrative complexity (501-1,000 rooms, and >1,000 rooms), the adoption of technology to improve employee productivity did not significantly differ $(M s=6.05$ and 6.38, respectively; $p=$ .999). Otherwise, all other hotel size categories had significant $(p<.05)$ differences with respect to implementation of technologies to increase staff efficiency. These findings may indicate that increasing levels of technology will provide incrementally higher levels of efficiency as the hotel size increases, but at some level of administrative complexity (e.g., 500 rooms), further additions of technology may provide diminishing returns in productivity.

Revenue-enhancing strategic priority. In examining the degree to which administrative complexity affects the implementation of revenue-enhancing technologies, overall effects indicated that the greater the administrative complexity (i.e., more hotel rooms), the greater the adoption of technology to increase revenue $(F=186.50, d f=9, p=.000)$. Inpost- hoc comparisons, there were significant differences in all administrative complexity categories and the number of revenue-enhancing technologies adopted with the exception of small hotels falling into categories of fewer than 20 rooms, 21 to 30 rooms, and 31 to 60 rooms ( $M s=$ $2.47,2.42$, and 2.67 , respectively; $p>.10$ for all three categories) and large hotels falling into the categories of 501 to 1,000 rooms and more than 1,000 rooms ( $M s=6.04$ and 6.38, respectively; $p=$.999). There were significant differences, however, across hotels with 61 to 100 rooms $(M=3.05), 101$ to 150 rooms $(M=3.42), 151$ to 200 rooms $(M=3.97)$, and 201 to 250 rooms $(M=4.49)$, and all other hotel size categories $(p<.05$ for all 
comparisons). Again, these findings appear to indicate that revenue-enhancing technologies are effectively used as administrative complexity increases, but at some level of administrative complexity (e.g., 500 rooms), additional technologies may not provide an increase in profitability.

\begin{tabular}{|c|c|c|c|c|c|c|c|c|c|c|c|}
\hline \multirow{2}{*}{$\begin{array}{l}\text { Strategic } \\
\text { Technology } \\
\text { Priority }\end{array}$} & \multicolumn{10}{|c|}{ Complexity (hotel size - number of rooms) } & \multirow[b]{2}{*}{$F^{a}$} \\
\hline & $<20$ & $20-30$ & $31-60$ & $61-100$ & $101-150$ & $151-200$ & $201-250$ & $251-500$ & $501-1,000$ & $>1,000$ & \\
\hline Guest service & $\begin{array}{l}3.29_{a} \\
(1.33)\end{array}$ & $\begin{array}{l}2.74 b \\
(1.24)\end{array}$ & $\begin{array}{l}2.82_{c} \\
(1.35)\end{array}$ & $\begin{array}{l}3.16_{d} \\
(1.35)\end{array}$ & $\begin{array}{l}3.65_{b, c, d} \\
(1.39)\end{array}$ & $\begin{array}{l}4.11_{a, b, c, d} \\
(1.39)\end{array}$ & $\begin{array}{l}4.79_{a, b, c, d} \\
(1.53)\end{array}$ & $\begin{array}{l}5.45_{a, b, c, d, e} \\
(1.57)\end{array}$ & $\begin{array}{l}6.52_{a, b, c, d} \\
(1.71)\end{array}$ & $\begin{array}{l}6.75_{a, b, c, d,} \\
(2.18)\end{array}$ & $\begin{array}{l}\text { d,e } \\
134.86\end{array}$ \\
\hline $\begin{array}{l}\text { Employee } \\
\text { productivity }\end{array}$ & $\begin{array}{l}2.46_{a, d} \\
(1.06)\end{array}$ & $\begin{array}{l}2.35_{b, d} \\
(1.02)\end{array}$ & $\begin{array}{l}2.71_{c, d} \\
(1.21)\end{array}$ & $\begin{array}{l}3.10_{a, b, c, d} \\
(1.25)\end{array}$ & $\begin{array}{l}3.41_{a, b, c, d} \\
(1.34)\end{array}$ & $\begin{array}{l}3.81_{a}, b, c, d \\
(1.35)\end{array}$ & $\begin{array}{l}4.27_{a, b, c, d} \\
(1.66)\end{array}$ & $\begin{array}{l}5.10_{a, b, c, d} \\
(1.66)\end{array}$ & $\begin{array}{l}6.05_{a, b, c, d} \\
(1.81)\end{array}$ & $\begin{array}{l}6.38_{a, b, c} \\
(1.96)\end{array}$ & 173.11 \\
\hline $\begin{array}{l}\text { Revenue en- } \\
\text { hancement }\end{array}$ & $\begin{array}{l}2.47_{\mathrm{add}, \mathrm{e}} \\
(1.05)\end{array}$ & $\begin{array}{l}2.42_{\mathrm{b}, \mathrm{d}, \mathrm{e}} \\
(1.00)\end{array}$ & $\begin{array}{l}e^{2.67_{\mathrm{c}, \mathrm{d}, \mathrm{e}}} \\
(1.22)\end{array}$ & $\begin{aligned}= & 3.05_{a, b, c, d, e} \\
& (1.30)\end{aligned}$ & $\begin{array}{l}3.42_{a, b, c, d, e} \\
(1.38)\end{array}$ & $\begin{array}{l}3.97_{a, b, c, d, e} \\
(1.32)\end{array}$ & $\begin{array}{l}4.49_{a, b, c, d, e} \\
(1.59)\end{array}$ & $\begin{array}{l}5.21_{a, b, c, d, e} \\
(1.60)\end{array}$ & $\begin{array}{l}6.05_{a, b, c, d, e} \\
(1.81)\end{array}$ & $\begin{array}{l}6.38_{a, b, c} \\
(1.97)\end{array}$ & 186.50 \\
\hline
\end{tabular}

Note: Standard deviations are in parentheses. Means with the same subscript are significantly different at the .05 level. a. Significant at the .001 level.

Table 7 Implementation of technologies by administrative complexity (means)

\section{Conclusions}

The importance of aligning IT choices with the strategic objectives of a hotel will increase in importance as hospitality executives search for additional mechanisms to obtain competitive advantage. IT decisions can play an important role in areas such as productivity, revenue enhancement, and guest service; however, they have been largely underutilized in the area of guest services. The findings from this study show that technologies designed to improve guest services, such as in-room Internet access and in-room fax machines, while frequently touted, are not currently given strategic priority in the U.S. lodging industry. In fact, guest service technologies were the least frequently adopted by the more than 4,000 hotels in our study. The results show that the U.S. hospitality industry has generally employed a strategy of first adopting technologies that address improved employee productivity and second those that enhance revenue generation.

The strategic choice to use technology for employee productivity is consistent with the work of Montealegre (1999) and others who argue that the first phase of technology adoption is to find a solution to a problem. As the pattern of adoption of IT in hotels is examined, it appears that properties that have adopted only one or two technologies strategically select productivity initiatives first. Productivity factors may be the first choice because they are based on more mature technologies and can be easily purchased from experienced vendors who offer products and support that fit with existing resources, skills, and systems.

While this study did not examine the motivation for IT choices, it may be speculated that the productivity preference is driven by cost-minimization objectives and the existence of mature and easy to implement vendor-developed technologies. The choice of productivityfocused technologies may also be the result of a traditional mindset that treats IT as a "cost center" rather than as an enabler of value (Luftman and Brier 1999). Hoteliers may also be 
limited by a low-tech- high-touch paradigm that does not encourage the use of technology to handle guest service activities (Bitner, Brown, and Meuter 2000).

A second question of interest in this study was whether the selection of IT would vary within the U.S. lodging industry on the basis of segment, organizational complexity, affiliation, and lodging type. Significant differences were found but did not support the pattern of difference suggested in the literature. It was expected that budget, economy, and midscale segments would pursue productivity strategies, while high- end segments would focus on guest service strategies. Interestingly, the findings of this study indicate that the budget and economy segments invested in fewer IT strategies in each strategic category. Regardless of strategic priority, luxury hotels adopted more technologies and chose to invest in all three categories of technology.

This study revealed that the commitment to adopting IT to enhance the business was greater in luxury and upscale hotels and lower in economy and budget hotels. More IT development was also present in convention hotels, conference centers, and casinos. IT was adopted to a significantly lower degree in other types of lodging establishments, with the lowest levels of adoption found in motels and bed- and-breakfasts.

U.S. chains and independents varied in their use of technologies to improve productivity and revenue but did not differ in their use of guest service technologies. That is, chains have not chosen to use guest service technologies to differentiate themselves from independents, nor have independents used technology to distinguish themselves from chains. For independent hotel operators, a promising approach would be to focus on in-room guest technologies, simply because chains have not invested as heavily in this IT strategy, and it may be the most viable source of competitive advantage. However, several chains in the past year have begun to aggressively direct their IT efforts to increase guest services. For example, Wingate is wiring 62 hotels for free, high-speed Internet in-room access; similarly, Hilton and Starwood's W Hotels are also actively installing high-speed access (Beirne 1999).

Perhaps in the past, chains have focused on productivity and revenue enhancement because these are sources of differentiation when attracting franchisees. In addition, they can rely on economies of scale to reduce costs and enhance the brand when developing and providing these types of technologies. It is also likely that guest-focused technologies may prove more expensive and require state-of-the-art knowledge that is untested and requires different implementation and operational resources and skills.

Finally, this study found that larger, complex hotels implemented more IT than did smaller hotels, thus supporting the assertion that the more complex the hotel operation, the greater the reliance on technology. There does appear to be a ceiling in the level of administrative complexity beyond which no greater technological implementation is required.

The pattern of differences revealed in this study provide support for Keltner et al.'s (1999) position that an industry may not be the most appropriate level of analysis for 
conducting studies. Indeed, the variation in IT adoption across the sectors of the U.S. lodging industry provides a possible explanation for the previously equivocal conclusions about the degree to which the hospitality industry has embraced technological innovations. For some segments (upscale and luxury) and lodging types (convention centers and casinos), IT appears to be extensive and to encompass all three strategic priorities; on the other hand, the use of IT is somewhat limited in the remaining segments and lodging types. For some strategic categories (employee productivity), IT appears to be widespread, but for other strategic categories (revenue enhancement, guest services), IT appears to be limited.

The data suggest that the U.S. lodging industry clusters by extent of IT usage. Larger, upscale hotels with gaming and convention business extensively use IT. They rank high on their use of all three types of strategic technologies. In light of our findings, there is some preliminary support for a pattern of technology adoption that begins with productivity improvement, moves to revenue enhancement, and then to the implementation of guest-service technologies. The evidence favors an evolutionary versus strategic alignment model of IT adoption in hospitality in which the larger, high-end, more business-focused hotels are further along the evolutionary adoption path.

For those managers looking to adopt new IT strategies, the efforts of convention centers, luxury hotels, and casinos might be instructive. The numerous best practice champions discussed in this article would also be useful models when considering how to approach IT. In our interviews with the best practice champions, several enablers for the successful adoption of IT were revealed (Siguaw and Enz 1999). Gaining support of senior management was repeatedly mentioned as an essential first step. Involving marketing and operations personnel in IT decisions and projects further assures more complete buy-in and more successful acceptance of new technologies. Ascertaining that adequate training is provided and that people are able to see the benefit from technology is important. If third party systems are used, taking the time to conduct careful research is essential to making the best vendor choices. Finally, technology is a continuously changing area; flexible systems that can be modified and upgraded easily should be selected to maximize the return on the investment.

As technological advances continue to emerge, hotels will be required to make dramatic changes. This research is a first effort to examine the alignment of IT to strategic intentions in various segments of the lodging industry. Our results are a beginning point in understanding the extent of technology use and the strategic focus of current practice. The evidence suggests that efforts to employ IT to enhance guest service, while underutilized in many sectors of the U.S. lodging industry, is a promising area for future development and competitive positioning. The use of technology is rapidly and dramatically changing the industry from its previously lowtech-high-touch mindset. To enhance competitive advantage, managers will need to incorporate more guest-service technologies within their key offerings to customers or be left behind. The infusion of technology to provide personalized services, service recovery, and other 
guest-service needs is the next wave and potentially the most sweeping new use of IT to affect the lodging industry.

\section{References}

Arthur Andersen (1999). “Hospitality 2000: The Technology." Survey conducted for New York University's Center for Hospitality, Tourism, and Travel Administration.

Bacheldor, B. (1999). "Hospitality \& Travel: A Trip to Grandma's Goes High Tech." Information Week, September 27, $189 \mathrm{ff}$.

Baker, S. (1999). “Global E-Commerce, Local Problems.” Journal of Business Strategy (July/August): 32-8.

Beirne, M. (1999). "Hoteliers Racing to Offer Business Travelers High-Tech Amenities," Brandweek, 40 (32): 4.

Bitner, M., S. Brown, and M. Meuter (2000). "Technology Infusion in Service Encounters." Journal of the Academy of Marketing Science, 28 (winter): 138-49.

Champy, J. (1996). Reengineering Management: The Mandate for New Leadership. New York: HarperCollins.

Cho, W., and M. D. Olsen (1998). "A Case Study Approach to Understanding the Impact of Information Technology on Competitive Advantage in the Lodging Industry." Journal of Hospitality \& Tourism Research, 22 (4): 376-94.

Clemons, E. K. (1986). "Information Systems for Sustainable Competitive Advantage." Information \& Management, 11 (3): 131-36.

Dewar, R., and J. Hage (1978). "Size, Technology, Complexity, and Structural Differentiation: Toward a Theoretical Synthesis." Administrative Science Quarterly, 23: 111-36.

Dube, L., C. A. Enz, L. M. Renaghan, and J. A. Siguaw (1999). American Lodging Excellence: The Key to Best Practices in the U.S. Lodging Industry. New York: American Express and American Hotel Foundation.

Glazer, R. (1999). “Winning in Smart Markets.” Sloan Management Review (summer): 59-69.

Hammer, M. (1996). Beyond Reengineering: How the Process-Centered Organization Is Changing Our Work and Our Lives. New York: HarperCollins.

Huo, Y. H. (1998). "Information Technology and the Performance of the Restaurant Firms." Journal of Hospitality \& Tourism Research, 22 (3): 239-51.

Keltner, B., D. Finegold, G. Mason, and K. Wagner (1999). "Market Segmentation Strategies and Service Sector Productivity." California Management Review, 41 (summer): 84-102. 
King, J. L., V. Gurbaxani, K. L. Kraemer, F. W. McFarlan, K. S. Raman, and C. S. Yap (1994). "Institutional Factors in Information Technology Innovation." Information Systems Research, 5 (2): 139-69.

Luftman, J., and T. Brier (1999). "Achieving and Sustaining Business-IT Alignment." California Management Review, 42 (1): 109-21.

Marshall, J. (1999). “Filling a Lucrative Slot.” US Banker, 109 (October): 62-5.

McFarlan, F. W. (1984). "Information Technology Changes the Way You Compete." Harvard Business Review, 62 (3): 98-103.

McKenney, J. L. (1994). Waves of Change: Business Evolution through Information Technology. Boston: Harvard Business School Press.

Meyers, C. (1999). “October News: Closing the Technology Gap.” Successful Meetings (October): 13.

Montealegre, R. (1999). "A Temporal Model of Institutional Interventions for Information Technology Adoption in Less-Developed Countries." Journal of Management Information Systems, 16 (summer): 207-32.

Porter, M. E. (1985). Competitive Advantage: Creating and Sustaining Superior Performance. New York: Free Press.

Senge, P. M. (1994). The Fifth Discipline: The Art and Practice of the Learning Organization. New York: Currency/Doubleday.

Senge, P. M., A. Kleiner, C. Roberts, G. Roth, and R. Ross (1999). The Dance of Change. New York: Currency/Doubleday.

Siguaw, J. A., and C. A. Enz (1999). "Best Practices in Information Technology." Cornell Hotel and Restaurant Administration Quarterly, 40 (October): 58-71.

Sweat, J., and J. Hibbard (1999). "Customer Disservice." Information Week, June 21, 65-78.

Whitford, M. (1999). “Maximizing Messaging.” Hotel \& Motel Management, September 6, 58.

Woodyard, C. (1999). "Hotels Fired Up to Get Wired Up: Industry Rushes to Please Laptoptoting Guests Who Want Fast Track to Web." US Today, September 2, $1 \mathrm{~B}$. 